\title{
Zetknięcie. Kultura organizacyjna muzeum a zwiedzający w świetle zapisów w księgach gości
}

Abstract

\section{Contact: Organizational Culture of the Museum and Visitors in the Light of Entries in Guest Books}

The paper deals how to define relations between guests and organizational culture in museum. Guest books are lectured at temporary exhibitions presented at the Museum of Warmia and Mazury in Olsztyn, from the half of $20^{\text {th }}$ Century up today. They are the source of analysis of the characteristics of the relationship between the museum and visitors as well as the review of opinions and assessments when receiving the exhibition. The exhibition is a product of the museum's organizational culture. The culture is the process and state that determines the hierarchy of values and activities, it decides about the identity of employees, as well as about the convictions the institution about itself. Statements about the museum and exhibitions, recorded in guest books, reflect the characteristics of organizational culture and they signal various ways of self-identification of the recipients of the exhibition. Contact is understood here as a state of compliance of the museum's mission and strategy as well as the intentions and goals of the visitor. Analysis of entries due to content will allow to find answers to the following questions: What are the symptoms of connecting the visitor to the museum? Which elements of the museum's organizational culture are distinguished by the visitor? What are the characteristics of the space of "contact"?

Keywords: museum, organizational culture, guest, self-identity, relation

Słowa kluczowe: muzeum, kultura organizacyjna, zwiedzający, autoidentyfikacja, relacja 
Wprowadzenie

w adidasach również można wejść na zamek [Księga... 2016-2018]

Postrzeganie muzeum jako przestrzeni odrębnej, takiej, w której należy być odpowiednio ubranym, jest sygnałem dla kultury organizacyjnej muzeum, że jest ono odczytywane w kategoriach niecodziennej rzeczywistości, niezwykłości, powagi lub komicznego dla ogółu odstawania od powszechnie przyjętych norm. Niech spostrzeżenie zwiedzającego stanie się punktem wyjścia następujących pytań badawczych: Jakie są przejawy związania zwiedzającego z muzeum? Które elementy kultury organizacyjnej muzeum są wyodrębniane przez zwiedzającego? Jakie są cechy przestrzeni „zetknięcia”?

Muzeum Warmii i Mazur ma złożoną przeszłość. Pod obecną nazwą funkcjonuje od 1975 roku. W 1945 roku powstało jako Muzeum Mazurskie, w zamku w Olsztynie, w którym od lat dwudziestych XX wieku do końca II wojny światowej istniało Heimatmuseum. Jego zadaniem było kształtowanie tożsamości lokalnej i więzi narodowych na podstawie artefaktów z przeszłości regionu [Traba 2005: 92-93]. Po II wojnie światowej zamek kapituły pozostał siedzibą główną muzeum, które z biegiem lat powiększano, dołączając do niego oddziały, mieszczące się w pałacach, zamkach i innych zabytkach architektury w regionie: w Reszlu, Szczytnie, Morągu, Lidzbarku Warmińskim i Mrągowie. Organizacja funkcjonuje w niełatwych warunkach społecznych, kulturowych oraz ekonomicznych, które szczegółowo charakteryzuje raport opracowany w 2012 roku [Fatyga et al. 2012: 146-147].

Kolekcje muzeum obejmują zbiory sztuki dawnej, współczesnej, rzemiosła artystycznego, zabytki archeologiczne i numizmaty, dokumenty osobiste, akta instytucji, fotografie, kartografię, sztukę ludową i przedmioty użytkowe z XIX i XX wieku, a także zbiory przyrodnicze. Muzealia są prezentowane na ekspozycjach czasowych i stałych, obok wystaw i zabytków wypożyczanych z innych muzeów oraz od prywatnych kolekcjonerów. Tak jak i w innych muzeach, od lat są też realizowane warsztaty, lekcje dla dzieci i młodzieży oraz rozmaite formy spotkań tematycznych dla dorosłych [Skurpski 1973: 557-559].

\section{Przeğląd literatury i pojęć oraz metodologia}

Badania odbiorcy oferty muzeów koncentrują się przede wszystkim na statystycznym badaniu cech demograficzno-społecznych, na odkrywaniu potrzeb i stopniu zaspokojenia potrzeb i preferencji zwiedzających [Ciemniewska, Pliszka 2015: 5; Macalik, Pluta-Olearnik 2017: 261]. Jest to także monitoring frekwencji. Bardziej szczegółowe badania pozwalają określić zamożność gościa muzeum, możliwości płacenia za ofertę i ocenę powiązanych z opłatami korzyści zwiedzającego. Co ciekawe, 
tani lub bezpłatny wstęp jest zachętą tylko dla co trzeciej osoby deklarującej chęć odwiedzenia muzeum [Murzyn-Kupisz 2016: 44-46]. Coraz bardziej rozbudowanym analizom odbiorcy towarzyszy tendencja do przekierowywania działalności muzealnej w stronę zaspokajania oczekiwań i potrzeb zwiedzających, traktowanych czasem jak konsumenci.

W niniejszym tekście celem analizy nie jest ustalenie prawidłowości w relacjach między ofertą kulturalną a odbiorcą [Kostera 1996: 33-34, 41-43; Gorzko 2016: 99-100]. Celem jest charakterystyka zetknięcia oraz opis przestrzeni pragmatycznej i mitycznej, w jakiej się ono dokonuje - według definicji Yi-Fu Tuana [1987: 29-30]. Zetknięcie jest kluczem do relacji między odbiorcą a wystawą i samym muzeum, to założenie wynika po części z przypuszczeń co do uwspólnionego interpretowania rzeczywistości, po stronie muzeum i przez jego gości [Gibbs 2011: 20]. Wskaźnikiem tych potencjalnych stanów zgodności dążeń między muzeum a odbiorcą są w długiej perspektywie czasowej - opinie zwiedzających (np. oceny, cechy relacji, więzi, sposoby autoidentyfikacji, wyodrębnianie elementów kultury organizacyjnej muzeum), zawarte w księgach gości, wystawianych na wystawach w Muzeum Warmii i Mazur po 1945 roku. Odbiorcy, zwiedzający, nie są tu zbyt szczegółowo charakteryzowani, są to ci, którzy przyszli do muzeum i zostawili komentarz w księdze gości na wystawie i w określony sposób dali się poznać w obrębie zetknięcia, w reakcji na kulturę organizacyjną muzeum.

W analizie wykorzystano tę teorię kultury organizacyjnej, która odczytują ją jako rdzenną metaforę organizacji [Chmielewska-Muciek 2009: 323]. Oznacza to, że kultura organizacyjna nie jest własnością struktury organizacji, ale efektem praktyk i dążeń pracowników, niekoniecznie poddaje się wpływom menedżerów i zarządzających spoza muzeum, wpływom zwiedzających oraz że nie jest zewnętrzna wobec członków organizacji, czyli odzwierciedla jej historię, jest holistyczna oraz widoczna w rytuałach i symbolach. Jest dokładnie tym, czym pracownicy i organizacja są, chcą być, tym, co wyraża się w całej ich działalności [Morgan 2013: 10-11, 126]. Jak każda organizacja, muzeum realizuje własne praktyki oraz posiada swoiste wymiary wartości, które w wielu definicjach są wymieniane jako zasadniczy składnik kultury organizacyjnej [Hofstede 2000: 44-45; Schein 2010: 23-32]. W wypadku tej analizy kultura organizacyjna jest metaforą społecznie obowiązujących wartości i norm dotyczących polskiej i regionalnej historii, tradycji oraz dziedzictwa i pamięci, a także tych wartości i norm, które rządzą relacjami międzyludzkimi. Znajdują one odbicie w ocenie ról pracowników oraz ocenie estetyki i użyteczności oferty muzealnej oraz całościowo pojętej instytucji.

Zetknięcie jest tu rozumiane jako symboliczny efekt konfrontacji i kooperacji, w którym spotykają się zinternalizowane wartości zwiedzającego z organizacją jako metaforą idei, działań, stanów i rzeczy cennych, preferowanych w muzeum. Podczas konfrontacji ustalane są rangi dążeń, zamiarów, celów postrzeganych podobnie, i tych, których wykładnia jest odmienna. Jest to efekt podjęcia współpracy 
i wysiłku interpretacji działania - po stronie zwiedzającego i po stronie muzeum, co Anselm Strauss przedstawił za pomocą procesu komunikacyjnych aktów nazywania, klasyfikowania, oceniania [Strauss 2013: 24-27]. Muzeum wychodzi naprzeciw odbiorcy, dostosowując tematykę i aranżację wystaw oraz pozostałą ofertę, a także tak konstruując swoją obecność w przestrzeni rzeczywistej i wirtualnej, by dopasować styl komunikacji do własnych cech oraz do możliwości i potrzeb odbiorcy. Zwiedzający z kolei komentuje to we wpisach do ksiąg gości, w komunikacji bezpośredniej, a także na forach internetowych, które nie są tu przedmiotem analizy. W ten sposób realizuje się zasadnicza warstwa zetknięcia. Zetknięcie jednak to nie tylko układ, w którym zachodzi realny kontakt zwiedzającego z wystawą czy inną ofertą muzealnej działalności. Bardziej precyzyjne wydaje się zdefiniowanie zetknięcia jako momentu zgodności intencji i celów zwiedzającego z misją i strategią muzeum oraz jako uwspólnionego efektu dynamiki relacji między gościem a muzeum.

Wspomniano, że proponowany tu ogląd opiera się na analizie wpisów/notatek w księgach gości - czyli opinii i ocen na temat wystaw, w których ludzie uczestniczą, które przeżywają i poznawczo interpretują. Pominięte zostały wpisy w rzeczywistości wirtualnej, gdyż w ich wypadku zetknięcie znacząco zmienia swój charakter. Opinie wyrażane na forach internetowych nie muszą powstawać w wyniku faktycznego zwiedzania muzeum - można obejrzeć zdjęcia lub poczytać opinie innych, problematyczne jest też to, że najczęściej nie zostały dokonane in situ.

Ekspozycje są tu traktowane jako specyficzne wytwory o społecznej wymowie mają sporo cech raportu z badań, w którym za pomocą tekstu, ikonografii i przedmiotu muzealnicy wyrażają założone idee i prezentują zasadnicze wartości kultury organizacyjnej. Wpisy w księgach gości Muzeum Warmii i Mazur odzwierciedlają interpretacje tych wystaw, powstających w rozmaitych kontekstach społecznych, po II wojnie światowej. Tematy, tytuły i cele ekspozycji, których dotyczą wpisy, nie są tu wyróżnione, jako że wszystkie są przekazem kultury organizacyjnej muzeum w danym czasie jej trwania. W analizie wykorzystuje się gęsty opis oraz elementy teorii ugruntowanej, w której badacz, czasowo zawieszając wiedzę i doświadczenie oraz wielokrotnie odczytując tekst, odkrywa znaczenia sformułowane przez zwiedzających [Lofland et al. 2009: 258-259]. Zapisy czytane po raz pierwszy pozwalają określić ich ogólne cechy i sformułować pierwsze pytania, kolejne czytania, wykonane już przez pryzmat pytań badawczych, służą wgłębianiu się w znaczenia, szukaniu procesu zmiany cech wpisów na przestrzeni lat i w zależności od rodzaju wystawy, wreszcie - pozwalają uporządkować analizę przez kodowanie treści [Charmaz 2009: 63-65, 82-85]. Jedną z jej zasad jest podejście nomotetyczne, gdyż odbiorca ma tendencję do podobnych zachowań w podobnych miejscach, do zwracania większej i mniejszej uwagi na wybrane aspekty ekspozycji, cechuje go oczekiwanie na doznania poznawcze, zmysłowe i emocjonalne [Gibbs 2011: 26-27]. Inną istotną zasadą analizy jest konieczność określenia cech badacza, zarówno tych przydatnych, jak i tych zaciemniających analizę, wynikających z zaangażowania w pracę w muzeum. 
Pożądana, czyli dogłębna, znajomość instytucji wiąże się z nieuniknionym stereotypizowaniem odbiorcy, często nieujawnianym, ale obecnym w najgłębszych warstwach kultury organizacyjnej [Wyka 1993: 25-26]. Wreszcie ważne wydaje się to, że wpisy w księgach gości mogą się stać narzędziem zmiany instytucji, gdyż potencjalnie wywołują bodźce, które w konsekwencji uruchomią przekształcenie kultury organizacyjnej muzeum. Analiza zetknięcia może zapobiec zamykaniu się organizacji w przestrzeni definicji rzeczywistości, formułowanych przez nią samą.

\section{Jakie są przejawy związania zwiedzająceg̉o $z$ muzeum?}

Historia, zabytki i przemili ludzie powodują, że warto tu wracać [Księga... 2016-2018]

Wskazanie na więź między gościem a muzeum sugeruje opisywanie poruszonego tu problemu nieco od końca, gdy zetknięcie w prostym ujęciu już się dokonało. Taka kolejność umożliwia jednak określenie tego, co tu ma być sednem zetknięcia, czyli zgodności postaw gościa oraz misji i strategii organizacji.

Gość muzeum bezpośrednio formułuje swoje związanie z organizacją, gdy wiele razy obiecuje, „na pewno tu wrócimy (...) nieodpuścimy [sic!] następnej wizyty”, „wrócimy, żeby zobaczyć wieżę” względnie - jest to pojedynczy zapis - „zostawcie tę księgę do za 10 lat, bo chcemy wrócić i zobaczyć ją jeszcze raz" [Księga... 2016-2018]. Można zakładać, że ludzie podróżujący zwiedzają muzea i - jeśli są zachwyceni i znaleźli wspólną wartość - do nich powrócą lub namówią na to swoich znajomych. Z zapisów wynika, że ważna jest lojalność odbiorcy - pytanie tylko, czy wobec zwiedzania muzeów w ogóle, czy wobec „swojego”, lokalnego/regionalnego muzeum: „Najfajniejsze są pocztówki z przeszłości. Lepsze niż barokowy czajnik sprzed dwóch lat” [Księga 1992, sygn. 4/36]. Wydaje się, że ważne są takie trendy, jak wykształcenie mody na zwiedzanie i obietnica powrotów, bez względu na to, kto i w jakim muzeum ją realizuje: „po latach warto tu wrócić. Zachwyca za każdym razem" [Księga... 2016-2018]. Inne cechy związania gościa i muzeum są widoczne w żądaniach zaspokojenia potrzeb zwiedzającego, uzupełnieniu braków, naprawienia czegoś, w zapisach dotyczących refleksji ogólnospołecznych powstałych na podstawie relacji z instytucją, w zapisach polemicznych i dialogu. Jeszcze inne elementy związania ujawniają się w autoidentyfikacji gościa, w sposobie, jaki prezentuje on siebie i swoje stany emocjonalne, wywołane wizytą w muzeum [Gałęziowska 2016: 101-108]. Warto dodać, że zapoczątkowane wizytą zaufanie i otwartość wobec instytucji skłania zwiedzającego do ujawnienia tych cech, które uznaje za istotne w danej sytuacji: „Trzeźwy od 4 miesięcy [imię i nazwisko]” [Księga... 2016-2018].

Zasadnicza autoidentyfikacja gościa to przede wszystkim imię lub imię i nazwisko, czyli nadany czy przyjęty sposób określenia człowieka [Strauss 2013: 19-29]. Do takiego miana dodawane jest miejsce zamieszkania lub pochodzenia, uzupełnione 
(lub nie) bardziej szczegółową, na przykład wartościującą, identyfikacją, jak choćby „mieszkańcy staropolskiego Raciborza” [Księga... 1990]. W młodszych księgach gości obok tych informacji pojawia się określenie stanu rodzinnego - przez wymienienie dzieci, zaznaczenie pokrewieństwa i powinowactwa osób towarzyszących. Zwiedzający przedstawia się również za pomocą własnego kapitału kulturowego: „miłośniczka sztuki z Krakowa” [Księga... 1962, sygn. 4/33]; używa do samoopisu kategorii wykształcenia - w rodzaju uczniowie z rozmaitych szkół czy studenci, lub statusu społecznego bądź zawodowego: „Największemu polskiemu miłośnikowi astronomii pokłonił się prezes lubelskiego oddziału Polskiego Towarzystwa Miłośników Astronomii” [Księga... 2010], „toruńscy motocykliści” [Księga... 2016-2018]. Szczególni indywidualiści używają niekonwencjonalnych samoopisów: „Gumiś, „Platerówka tu była”, „Piotr Templariusz”, „wdzięczna poetka ze Śląska”, „Cześć, to ja pożeracz". Takie samookreślenia można interpretować jako próby zaznaczenia swojej odrębności, istotności - w rezultacie zetknięcia z muzeum.

Autoidentyfikacja gości często pozwala się domyślać, że „Związanie” z muzeum, z jego ofertą, nie musi dotyczyć pojedynczego gościa, ale takiego, którego należałoby scharakteryzować przez pryzmat przynależności do mniej lub bardziej trwałej grupy: „Hej wy to my” [Księga... 1992, sygn. 4/36]. Zapisy w księgach gości są wykonywane przez przedstawicieli, „piszących”, i potwierdzane są podpisem lub rysunkiem przez pozostałych uczestników. Tymczasowy status członka większej grupy podkreślają urlopowicze, kolonie letnie, obozy harcerskie, wędrowne, uczestnicy rajdów [Księga... 1962, sygn. 4/33].

Innym przejawem związania z muzeum jest logistyka zwiedzających w stosunku rocznym, czyli to, w jakich okresach wzrasta liczba gości. Związanie z muzeum jest tu interpretowane przez pryzmat zachowań uważanych za obowiązkowe podczas urlopu, mody na pójście do muzeum w związku z cyklicznymi wydarzeniami czy ze względu na sentyment powrotu do miejsc znajomych. Prawidłowością jest natężenie zwiedzających w lecie i spadek w zimie, co najpierw wykazali muzealnicy w księdze z lat 1941-1944 [sygn. DH 7990 OMO]. Powojenne notatki o liczbie zwiedzających, uczynione przez pracowników muzeum w latach 1945-1954, wskazują podobną regularność [sygn. DH $8082 \mathrm{OMO}$ ]. Obecnie analiza sprzedaży biletów w muzeum również wykazuje takie tendencje. Można spekulować, jakie kategorie gości przychodzą do muzeum w poszczególnych okresach, ważne jednak jest, że nie ma okresów bez zwiedzających lub z ich minimalną liczbą. Warto przy tym zauważyć, że notatki sprzed kilkudziesięciu lat i obecne rozróżniają tych, którzy kupili bilet, i tych, którzy weszli bezpłatnie. Jedni generują zysk materialny, drudzy - wyłącznie frekwencję. Muzea dążą do sprzedania większej liczby biletów czy do zwiększenia frekwencji? W wypadku opisu zetknięcia liczyłaby się przede wszystkim frekwencja...

Wspomniano wcześniej, że związanie z muzeum jest obserwowalne w aspekcie formułowanych przez zwiedzających uczuć. Gość lubi dzielić się swoimi przeżyciami, odczuciami i stanami, a czasem swoistym zblazowaniem: „Przyszliśmy do muzeum 
bo bary otwierają o 14.00" [Księga... 2016-2018]. Wprawdzie według stwierdzenia Czesława Sikorskiego „preferowanie emocjonalnych kryteriów ocen jest naturalnym skutkiem niskiego poziomu wykształcenia" [Sikorski 2007: 203], ale w wypadku analizy wpisów do ksiąg gości warto je podkreślić. Wynikają one nie tylko z pewnego zasobu kulturowego, który właśnie w ten sposób każe nawiązywać relację i budować więź, ale z uzasadnionego zachwytu i chęci podzielenia się doznaniami: „pisząc ten krótki list chcielibyśmy pozostawić po sobie cząstkę swojej duszy w tych pięknych i tajemniczych murach tego niesamowitego zamku" [Księga... 2016-2018].

\section{Jaka jest kultura organizacyjna muzeum w oczach zwiedzająceģo?}

Najbardziej podobały mi się obrazy i skrzypiąca podłoga, opisy różnych zabytkowych rzeczy są długie i nudne, a komputery trochę się zacinają, ale mimo wszystko jest fajnie. [Księga... 2016-2018]

Usytuowanie Muzeum Warmii i Mazur w regionie o bardzo skomplikowanej przeszłości społecznej i politycznej każe przewidywać, że istotnym elementem jej kultury organizacyjnej są znaczenia przypisywane kulturze i dziejom, w szczególności procesom akulturacji, polityce lokalnej, trendom w interpretacji przeszłości: „Byłem tu 8 VIII 1990. I na pewno wrócę. Zadziwia mnie tak mało ciekawych a na pewno możliwych do zdobycia zbiorów z tych ziem, to wstyd” [Księga... 1990]. W zapisach gości często przywoływane jest zachowywanie polskości (wydarzeń, osób znaczących, dzieł sztuki), na przykład podziękowania za odbudowę zamku (co nie nastąpiło), walkę z Krzyżakami, znaczenie odkryć Mikołaja Kopernika, są to wpisy odsłaniające kłopoty z odróżnianiem Prusów i Prusaków, względnie pretensje o to, że muzeum nie spełnia wyrafinowanych oczekiwań co do tematyki ekspozycji: „Wielka szkoda, że brak zbiorów krakowskich. Trzeba się upomnieć o zwrot tej części dzieł kultury polskiej, które są magazynowane na terenie ZSRR w tym obrazów J. Chełmońskiego" [Księga... 1988-1989, sygn. 4/29]. Znaczące jest powtarzające się wskazanie na wartości autoteliczne: czyste piękno architektury i zabytków: „lubię zamki” [Księga... 2016-2018], aczkolwiek czasem z podtekstem: „fajne schody, dużo schodów, polecam" [Księga... 2016-2018]. W zamku nie ma windy, więc dostęp do części ekspozycji i pomieszczeń jest utrudniony lub niemożliwy w wypadku zwiedzających $\mathrm{z}$ dysfunkcją narządów ruchu.

Zwiedzający niejako zderzają się z wartością gromadzenia zabytków: „Bogactwem zbiorów muzealnych byliśmy mile zaskoczeni" [Księga... 1962, sygn. 4/33]. Odrobinę niepokojące może być powtarzające się przez lata stwierdzenie świadczące o stylu obecności kultury muzeum w sferze publicznej: „Jesteśmy mile zaskoczeni olsztyńskim muzeum na zamku" [Księga... 2016-2018]. Zwiedzający, idąc do zamku, nie ma informacji o tym, czego się spodziewać, a samo muzeum jest dla 
niego niewiadomą. Równie alarmujące są konkluzje o pięknych eksponatach, bez uwzględnienia, że za każdym razem ilustrują one ideę, że są narzędziem w szerszym przekazie: „bardzo wiele eksponatów do obejrzenia (...), bardzo ciekawe eksponaty (...), bogate zbiory" [Księga... 2016-2018]. Taka interpretacja w pewnym stopniu zależy od jednostkowych oczekiwań zwiedzającego, co ilustrują następujące zapisy, dotyczące tej samej ekspozycji: „wystawa bardzo pomysłowa” [Księga... 2016-2018] oraz „ładny żyrandol” [Księga... 2016-2018]. Takie wpisy sugerują, że zetknięcie z ekspozycją jest podobne do oglądania wystawy w sklepie, względnie oznacza niemożność oddzielenia wystawy od stałego wyposażenia sal ekspozycyjnych. Można również przywołać przykład niewątpliwie niezamierzonego przez kuratorów odczytania idei wystawy twórczości Stanisława Ignacego Witkiewicza: „Przed wizytą: jesteśmy ciekawi. Po wizycie: to musiały być klawe imprezy” [Księga... 1990].

Organizacja jest też metaforą wartości reprezentowanych przez pracowników muzeum, szczególnie tych, którzy wchodzą w relacje ze zwiedzającymi: są to przewodnicy muzealni, opiekunowie na salach ekspozycyjnych, strażnicy, dużo rzadziej pracownicy merytoryczni, jakkolwiek zwiedzający często nie rozróżniają funkcji zatrudnionych w muzeum. Odbiorcy wskazują głównie miękkie kompetencje komunikacyjne - zaangażowanie, życzliwość, współpracę, objaśnienia oraz stan wiedzy. Ze względu na funkcję zwiedzający identyfikują pracownika jako kustosza i jako przewodnika.

Wartości kultury organizacyjnej wyraźnie mają własną, zmieniającą się nieco w czasie, hierarchię. Zapisy o kulturze organizacyjnej w starszych księgach wyraźnie oddzielają muzeum od zwiedzających, czasem skrajnie oceniają rolę instytucji: „serdeczne słowa uznania dla organizatorów wystawy, a przede wszystkim dla Polski Ludowej, która taką pieczołowitością otacza pamiątki z przeszłości” [Księga 1962, sygn. 4/33]. Młodsze zapisy ten dystans niwelują, ocenie podlegają wyłącznie pracownicy pierwszego kontaktu (opiekunowie sal i przewodnicy): „Jesteśmy pod wrażeniem zbiorów i atmosfery, a przede wszystkim sympatii osób tu pracujących" [Księga... 2016-2018].

Muzeum, poprzez zachowywanie i badanie dziedzictwa, przekształca wiedzę ukrytą w dostępną [Sikorski 2007: 77]. Przykładowe wskazania tej cechy kultury poświadczają takie, być może nieco autoironiczne, wpisy: „Mówisz Kopernik, myślisz Toruń. Dopiero po podróży na Warmię odkryłem prawdę. Mój światopogląd zmienił się o $180^{\circ}$. Ta informacja mnie przerosła" [Księga... 2016-2018]. Bardzo wiele wpisów każe przypuszczać, że kultura organizacyjna muzeum, sama ta organizacja, jest często dla zwiedzającego niezwykle intrygująca. Wyraża się to w domaganiu się pokazania - schowanych najpewniej przed gościem - zabytków, otwarcia zamkniętych drzwi, udostępnienia pomieszczeń, a zwiedzający przy tym najczęściej poszukuje akcji, chce, żeby coś się działo [Goffman 2006: 190].

Kultura organizacyjna ma swoje wewnętrzne tempo, poprzez które prezentuje się środowisku zewnętrznemu. Jest to częstotliwość zmian wystaw czasowych, 
odświeżania wystaw stałych, a także optymalna ilość czasu, który należy poświęcić na wystawę, ofertę, przebywanie w zasięgu kultury muzeum. Odbiorca wystaw odczytuje to tempo, dopasowując się w mniejszym lub większym stopniu: „Wystawa bardzo interesująca. Chcielibyśmy jedynie aby przewodnicy oprowadzali zwiedzających cokolwiek wolniej. Przy tak dużej ilości eksponatów nie można ich wszystkich obejrzeć w ciągu jednej godziny” [Księga... 1962, sygn. 4/33]. Gość odczytuje to także w odniesieniu do całościowej działalności muzeum i daje temu taki wyraz: „z ogromną niecierpliwością czekamy na udostępnienie większej ilości [sic!] eksponatów, pragniemy, by nasze muzeum wróciło do dawnej postaci” [Księga... 1989-1990, sygn. 4/30].

\section{Na czym polega „zetknięcie”?}

Lubię historię i zwiedzanie więc trafiłem idealnie [Księga... 2016-2018]

Rozmaite typy działań podejmowane przez zwiedzających, niekoniecznie są racjonalne, nie zawsze uzasadnione, rzadko przemyślane [Haman 2014: 71-74]. Mimo to zetknięcie oddaje sytuację, w której następuje zgodność na płaszczyźnie celowych racjonalnych działań realizowanych przez muzeum i ich interpretacji dokonywanych przez zwiedzających. Zetknięcie ma cechy kooperacji, w której zwiedzający i muzeum ustalają wzajemne korzyści, możliwe do przyjęcia straty (np. koszt biletu, koszt ekspozycji, konserwacji muzealiów, poświęcony czas, wkład wysiłku/nadkład pracy, doznania zmysłowe i obciążenie relacją - stanem emocjonalnym powstałym w efekcie zetknięcia). Zetknięciem rządzą reguły ogólne, wynikające z norm ładu społecznego, reguły lokalne (np. obowiązek pozostawienia rzeczy w szatni, zakaz wprowadzania zwierząt, zakaz palenia na dziedzińcu zamku, zakaz fotografowania z lampą błyskową na ekspozycjach) oraz reguły konstruowane w procesie bezpośredniego kontaktu między kulturą organizacyjną i zwiedzającym (są to zazwyczaj zasady grzeczności, stany hałaśliwości, szybkość przemieszczania się - łącznie z bieganiem po salach muzealnych, negocjowane czasowe lub doraźne udostępnianie, użyczanie przestrzeni lub przedmiotów, udzielane wyjaśnienia itp.).

Zetknięcie ujawnia się w zapisach mówiących o doznaniach estetycznych. Jest to na przykład wyrażane w rozmaitych formach wskazanie, że „tu jest pięknie”. Uwidocznia się w zgodności moralnej - w podziękowaniach za udostępnienie zabytków, za zachowanie dziedzictwa, za podtrzymywanie pamięci o wydarzeniach i ludziach uznawanych za znaczących [Halbwachs 2008: 421-422]. Zetknięcie wyraża się również w sferze poznawczej - gdy zwiedzający sygnalizuje zmianę wiedzy w zakresie proponowanym przez muzeum, oraz emocjonalnej - gdy jest poruszony (zadowolony, zaniepokojony, zachęcony do refleksji). W sferze behawioralnej zetknięcie odzwierciedla się w stopniu uznania i respektowania wskazań co do kierunków 
poruszania się, uwzględnienia fizycznego dystansu dzielącego zwiedzającego od zabytku, przestrzegania różnych ograniczeń dostępu, godzin otwarcia. Płaszczyznę zetknięcia tworzą także elementy przestrzeni temporalnej i fizycznej, regulowane przez społecznie przyjęte godziny pracy, bezpieczeństwa, spędzania wolnego czasu i stylów rozrywki. Jak się wydaje, te wymiary przestrzeni łatwo podlegają uproszczonym oczekiwaniom. W pewnym stopniu tę płaszczyznę tworzy sfera zmysłów, choć jest ograniczona do słuchu, np. „skrzypiąca podłoga”, wrażeń wzrokowych oraz żalu wobec tego, że nie można wykorzystać zmysłu dotyku.

Znaczącą częścią zetknięcia jest relacja gościa z pracownikiem muzeum, zarówno z nim samym jak i z jego rolą. Jest on podmiotowym przedstawicielem kultury organizacyjnej muzeum. Poprzez zetknięcie prawdopodobnie wyraża się poczucie bezpieczeństwa oraz poziom niepewności, które to stany zwykle ustalają się podczas konfrontacji różnych/odrębnych/różniących się podmiotów. W zapisach odzwierciedla się to poprzez wskazanie powtarzające się w księgach z rozmaitych wystaw „jesteśmy mile zaskoczeni”. Wyjaśnienia tego stanu można szukać w procesach zachowywania twarzy [Goffman 2006: 41-43], kontroli statusu, wyrażania szacunku poprzez dawanie oraz swoistej wymiany, rozumianej jako „zasada społeczna ożywiająca charakter tych, którzy wspólnocie pragną się odwdzięczyć”" [Sennet 2012: 71].

Przypuszczalnie do zetknięcia nie dochodzi, gdy w grę wchodzą interesy tylko jednej strony i nie zostają one zaspokojone. Analiza wpisów do ksiąg skupia się na realnym kliencie muzeum, pozwala sprecyzować narzędzia skutecznego dotarcia do potencjalnego zwiedzającego i sprawić, by kupił bilet i zwiększył frekwencję, względnie tylko zwiększył frekwencję. Rozróżnienie tych dwóch płaszczyzn jest istotne o tyle, że wizyta w muzeum nie musi skutkować zetknięciem... Może to być tylko zwiedzanie.

\section{Podsumowanie}

W rezultacie analizy wpisów do ksiąg gości Muzeum Warmii i Mazur można przyjąć, że przestrzeń zetknięcia, to przestrzeń realizacji wartości kultury organizacyjnej, czyli pragmatyczna i mityczna przestrzeń muzeum: architektura, tematyka i aranżacja ekspozycji, realizacja funkcji i ról pracowników muzeum. Wytworzone zetknięcie ma moc zmiany poznawczej i emocjonalnej warstwy cech odbiorcy, ma także moc przyciągania odbiorcy - wytwarzania stanu powielania powrotów odbiorcy do muzeum. Cechy odbiorcy, jakiekolwiek by nie były, są wtórne do znaczenia kultury organizacyjnej muzeum. To odbiorca, przychodząc do muzeum, staje przed pytaniem, „kim jestem w tej sytuacji” [Strauss 2013: 47-48]. Kultura organizacyjna muzeum w dużym stopniu decyduje o odpowiedzi na to pytanie, poprzez ofertę, którą planuje i realizuje. Zestawienie cech odbiorcy, wskazanych przez niego samego z również przez niego wyodrębnionymi cechami kultury organizacyjnej muzeum, 
pozwala nazwać narzędzia, które w największym stopniu kształtują zetknięcie. Są to przypuszczalnie w największym stopniu te elementy kultury organizacyjnej muzeum, które najbardziej angażują poczucie podmiotowości odbiorcy, które każą mu napisać: „nie mamy u nas takiej wystawy / nie spodziewaliśmy się, że tu jest tak miło / u nas jest równie ładnie / u nas jest lepiej”. Ukłonem kultury organizacyjnej muzeum wobec jej gościa mogłoby być więc uwzględnienie tej podmiotowości, na przykład poprzez wprowadzenie biletów uwzględniających jego rozmaite tożsamości: poza biletami dla rodzin, seniorów, ulg studenckich, szkolnych, zniżek dla grup o określonej liczebności, warto tu wymienić takie specyficzne grupy, jak motocykliści, harcerze, kolonie letnie, narzeczeni, nowożeńcy w podróży poślubnej, paczki przyjaciół, mieszkańcy Olsztyna z gośćmi spoza miasta.

Są to także takie elementy, które podkreślają przyjazną i współpracującą odrębność: „wy-zabytki, my-rodzice/uczniowie/turyści” itp. Są to w szczególności te cechy kultury organizacyjnej, które są wskazane przez odbiorców jako znaczące, są eksponowane przez jej twórców i reprezentantów, bezpośrednio kontaktujących się z odbiorcą oraz przez samą ekspozycję. Jednorodne tematycznie przykłady są następujące:

Chcielibyśmy wyrazić słowa gorących podziękowań dyrekcji Muzeum za umożliwienie zwiedzania Muzeum, gdzie z pietyzmem zebrano i przechowuje się pamiątki świadczące o polskości tych ziem [Księga... 1975-1988];

Jako Polak mieszkający poza granicami kraju z wielkim zainteresowaniem zwiedziłem Muzeum Warmii i Mazur. Walka o polskość trwa nadal [Księga... 1980-1983];

Jesteśmy wzruszeni treścią ekspozycji upamiętniającej obecność Jana Pawła II na Warmii i Mazurach. To niewątpliwie pobudza naszą refleksyjność w wymiarze społecznym i religijnym. Pracownikom Muzeum dziękujemy za pieczołowite chronienie pamiątek bliskich naszym sercom [Księga... 2011];

za wspaniałe dziedzictwo kultury kształtującego się Państwa Polskiego pięknie dziękujemy [Księga... 2016-2018].

O zetknięciu w dużym stopniu decyduje więc stan kultury organizacyjnej, który wyraża się poprzez utożsamienie z nią pracowników muzeum, skutkuje nastawieniem do zwiedzających, na bazie wyrazistej oferty, która nie jest odczytywana jako „zbiór eksponatów”. Jest to także konkretna tematyka wystaw oraz style aranżacyjne, które, jakkolwiek podlegają ocenie i wyborowi, nie wydają się tu aż tak znaczące. Przypuszczalnie odbiorca uzna wartość oferty także wtedy, gdy nie będzie ona w pełni odpowiadać jego chwilowym oczekiwaniom (te nieobecne na zamku kanoników warmińskich księżniczki...), ale zaspokoi potrzebę wspólnoty wartości 
autotelicznych, a przede wszystkim będzie odzwierciedlać „rzeczywistą działalność organizacji” [Drucker 1995: 20].

$\mathrm{Z}$ analizy cech zetknięcia wynika ponadto, że nie każda oferta jest kompatybilna z każdym zwiedzającym - jest to oczywiste w teorii, w praktyce wydaje się, że muzea są dla każdego, a przynajmniej tak się starają. Jest to rezultat uproszczenia muzea są owszem dostępne, ale nie każda wizyta, nie każdego w każdym muzeum zaowocuje stanem, w którym „zetknięcie” będzie kompletne, czyli zrealizowane jednocześnie w sferze poznawczej, emocjonalnej, intelektualnej, towarzyskiej, społecznej - więziotwórczej. I nie należy tego oczekiwać. Ilustracją tego może być taki, bardzo radykalny, wpis: „Zamiast zrobić wystawę, która eksponowałaby wnętrze wyposażenie zamku wsadziliście nam kit z Kopernikiem. To nie jest muzeum. Ten zamek umiera" [Księga 1988-1989, sygn. 4/29].

Przypuszczalnie wytworzyły się już dość silne trendy nakazujące bywanie na wernisażach, zwiedzanie muzeów. Warto tylko zastrzec, że wernisaże w zależności od rangi wydarzenia ściągają społeczność lokalną, publiczność lojalną, zaangażowanych specjalistów, miejscowych notabli, osoby szczególnie zaangażowane w daną wystawę. Natomiast zwiedzanie wystaw już po wernisażach to przede wszystkim domena przyjezdnych, turystów, osób przypadkowych, choć także ekspertów, nie mówiąc o nałogowcach i maniakach muzealnych oraz ludzi podporządkowanych, czyli na przykład uczniów, wycieczki zorganizowane. We wszystkich wypadkach niezbędna jest silna kultura organizacyjna, by wytworzyło się takie zetknięcie, które miałoby charakter związania z wzajemnością, zobowiązania do podtrzymywania relacji, współodpowiedzialności za jakość tej relacji. Gość przyjezdny niekoniecznie musi być stałym bywalcem - wystarczy, że odwiedzanie muzeum stanie się częścią jego stylu życia, elementem spędzania czasu wolnego, relaksu, odpoczynku, a muzeum umożliwi mu to w granicach swojej misji i strategii [Macalik, Pluta-Olearnik 2017: 260-261]. Gość zaś, który jest sąsiadem muzeum, niechby znalazł i zapamiętał przyjemność w obcowaniu z kulturą organizacyjną muzeum podczas niedzielnych spacerów...

\section{Bibliografia}

\section{Źródła}

Muzeum Warmii i Mazur w Olsztynie - księgi wpisów zwiedzających:

Księga wpisów Heimatmuseum, 1938-1944, sygn. DH 8077 OMO.

Księga odwiedzających Heimatmuseum, 1941-1944, sygn. DH 7990 OMO.

Księga zwiedzających Muzeum Mazurskie, 1945-1954, sygn. DH 8082 OMO.

Księga pamiątkowa wystawy w zamku w Lidzbarku Warmińskim, 1962, sygn. 4/33.

Kronika. Księga pamiątkowa osób zwiedzających, 1967-1980, sygn. 4/32.

Księga pamiątkowa, 1975-1988, sygn. 3/31. 
Złota Księga, 1980-1983, sygn. 4/35.

Księga pamiątkowa osób zwiedzających, 1988-1989, sygn. 4/29.

Księga pamiątkowa osób zwiedzających, 1989-1990, sygn. 4/30.

Księga pamiątkowa wystawy „Ikona rosyjska. Dawne rzemiosło artystyczne”, 1990, brak sygn. Złota Księga pamiątkowa osób zwiedzających, 1990-1991, sygn. 4/34.

Złota Księga pamiątkowa osób zwiedzających, 1992, sygn. 4/36.

Złota Księga (prochy Mikołaja Kopernika w zamku w Olsztynie), III-IV 2010, brak sygn. Złota Księga. Wystawa „Jan Paweł II na Warmii i Mazurach”, IV 2011-XI 2011; brak sygn. Księga. Wystawa jubileuszowa, 2016-2018, brak sygn.

\section{Publikacje}

Charmaz K. (2009), Teoria ugruntowana. Praktyczny przewodnik po analizie jakościowej, tłum.

B. Komorowska, Warszawa: Wydawnictwo Naukowe PWN.

Chmielewska-Muciek D. (2009), Dyskusja nad pojęciem kultury organizacyjnej, „Annales Universitas Mariae Curie-Skłodowska", Sectio H, Oeconomia 43, s. 317-331.

Ciemniewska J., Pliszka S. (2015), Analiza odbiorców projektu e-muzea. Użytkownicy internetu, Warszawa: Polskie Badania Internetu.

Drucker P. (1995), Zarządzanie organizacja pozarządową. Teoria i praktyka, tłum. M. Wanat, Warszawa: Fundusz Współpracy, Program Phare Dialog Społeczny - NGOs.

Gałęziowska M. (2016), Zapis interakcji między muzeum a jego gościem jako obraz dynamiki więzi społecznych. Muzeum Warmii i Mazur po II wojnie światowej, „Warmińsko-Mazurskie Studia z Historii Najnowszej”, t. 1, s. 73-111.

Gibbs G. (2011), Analizowanie danych jakościowych, tłum. M. Brzozowska-Brywczyńska, Warszawa: Wydawnictwo Naukowe PWN.

Glaser B.G., Strauss A.L. (2009), Odkrywanie teorii ugruntowanej. Strategie badania jakościowego, tłum. M. Gorzko, Kraków: Zakład Wydawniczy Nomos.

Goffman E. (2006), Rytuał interakcyjny, tłum. A. Szulżycka, Warszawa: Wydawnictwo Naukowe PWN.

Halbwachs M. (2008), Społeczne ramy pamięci, tłum. M. Król, Warszawa: Wydawnictwo Naukowe PWN.

Haman J. (2014), Gry wokół nas. Socjologia i teoria gier, Warszawa: Wydawnictwo Naukowe Scholar.

Hofstede G. (2000), Kultury i organizacje. Zaprogramowanie umysłu, tłum. M. Durska, Warszawa: Polskie Wydawnictwo Ekonomiczne.

Kostera M. (1996), Postmodernizm w zarzadzaniu, Warszawa: Polskie Wydawnictwo Ekonomiczne. Lofland J., Snow D.A., Anderson L., Lofland L.H. (2009), Analiza układów społecznych. Przewodnik po badaniach jakościowych, tłum. S. Urbańska, M. Żychlińska, A. Kordasiewicz, Warszawa: Wydawnictwo Naukowe Scholar.

Macalik J., Pluta-Olearnik M. (2017), Publiczność muzealna w świetle badań marketingowych od frekwencji do satysfakcji klienta, „Handel Wewnętrzny”, nr 2 (367), s. 259-269. 
Morgan G. (2013), Obrazy organizacji, tłum. Z. Wiankowska-Ładyka, Warszawa: Wydawnictwo Naukowe PWN.

Murzyn-Kupisz M. (współpr. J. Działek) (2016), Instytucje muzealne z perspektywy ekonomii kultury, Kraków: Universitas.

Schein E.H. (2010), Organizational Culture and Leadership, $4^{\text {th }}$ ed., San Francisco: Jossey-Bass \& Wiley Inc.

Sennet R. (2012), Szacunek w świecie nierówności, tłum. J. Dzierzgowski, Warszawa: Warszawskie Wydawnictwo Literackie Muza.

Sikorski C. (2007), Drogi do sukcesu. Profesjonalizm kontra populistyczna kultura organizacyjna, Warszawa: Difin.

Skurpski H. (1973), Muzeum Mazurskie w latach 1945-1958, „Komunikaty Mazursko-Warmińskie", nr 4, s. 557-585.

Strauss A.L. (2013), Zwierciadła i maski. W poszukiwaniu tożsamości, tłum. A. Hałas, Kraków: Zakład Wydawniczy Nomos.

Traba R. (2005), „Wschodniopruskość”. Tożsamość regionalna i narodowa $w$ kulturze politycznej Niemiec, Poznań: Polskie Towarzystwo Przyjaciół Nauk, Warszawa: Instytut Studiów Politycznych PAN.

Tuan Yi-Fu (1987), Przestrzeń i miejsce, tłum. A. Morawińska, Warszawa: Państwowy Instytut Wydawniczy.

Wyka A. (1993), Badacz społeczny wobec doświadczenia, Warszawa: Wydawnictwo Instytutu Filozofii i Socjologii PAN. 